\title{
Information provision and preferences for education spending: Evidence from representative survey experiments in three countries
}

Citation for published version (APA):

Cattaneo, M., Lergetporer, P., Schwerdt, G., Werner, K., Woessmann, L., \& Wolter, S. C. (2019). Information provision and preferences for education spending: Evidence from representative survey experiments in three countries. ROA. ROA Research Memoranda No. 009 https://doi.org/10.26481/umaror.2019009

Document status and date:

Published: 05/12/2019

DOI:

10.26481/umaror.2019009

Document Version:

Publisher's PDF, also known as Version of record

Please check the document version of this publication:

- A submitted manuscript is the version of the article upon submission and before peer-review. There can be important differences between the submitted version and the official published version of record. People interested in the research are advised to contact the author for the final version of the publication, or visit the DOI to the publisher's website.

- The final author version and the galley proof are versions of the publication after peer review.

- The final published version features the final layout of the paper including the volume, issue and page numbers.

Link to publication

\footnotetext{
General rights rights.

- You may freely distribute the URL identifying the publication in the public portal. please follow below link for the End User Agreement:

www.umlib.nl/taverne-license

Take down policy

If you believe that this document breaches copyright please contact us at:

repository@maastrichtuniversity.nl

providing details and we will investigate your claim.
}

Copyright and moral rights for the publications made accessible in the public portal are retained by the authors and/or other copyright owners and it is a condition of accessing publications that users recognise and abide by the legal requirements associated with these

- Users may download and print one copy of any publication from the public portal for the purpose of private study or research.

- You may not further distribute the material or use it for any profit-making activity or commercial gain

If the publication is distributed under the terms of Article $25 \mathrm{fa}$ of the Dutch Copyright Act, indicated by the "Taverne" license above, 


\section{Maastricht University $\quad$ ROA}

Information provision and preferences for education spending: Evidence from representative survey experiments in three countries

Maria Cattaneo

Philipp Lergetporer

Guido Schwerdt

Katharina Werner

Ludger Woessmann

Stefan C. Wolter

\section{ROA Research Memorandum}

ROA-RM-2019/9

Researchcentrum voor Onderwijs en Arbeidsmarkt | ROA

Research Centre for Education and the Labour Market / ROA 


\title{
Information provision and preferences for education spending: Evidence from representative survey experiments in three countries
}

\author{
Maria Cattaneo \\ Philipp Lergetporer \\ Guido Schwerdt \\ Katharina Werner \\ Ludger Woessmann \\ Stefan C. Wolter
}

ROA-RM-2019/9

December 2019

Research Centre for Education and the Labour Market Maastricht University

P.O. Box 616, 6200 MD Maastricht, The Netherlands

$\mathrm{T}+31433883647 \mathrm{~F}+31433884914$

secretary-roa-sbe@maastrichtuniversity.nl www.roa.nl 


\section{Abstract \\ Information provision and preferences for education spending: Evidence from representative survey experiments in three countries*}

Do differences in citizens' policy preferences hamper international cooperation in education policy? To gain comparative evidence on public preferences for education spending, we conduct representative experiments with information treatments in Switzerland using identical survey techniques previously used in Germany and the United States. In Switzerland, providing information about actual spending and salary levels reduces support for increased education spending from 54 to 40 percent and for increased teacher salaries from 27 to 19 percent, respectively. The broad patterns of education policy preferences are similar across the three countries when the role of status-quo and information are taken into account.

JEL classification: H52, 122, D72, D83

Keywords: policy preferences, cross-country comparison, international cooperation, Switzerland, Germany, United States, education spending, survey experiments

\author{
Maria Cattaneo \\ Swiss Coordination Centre for Research in \\ Education \\ Entfelderstrasse 61 \\ $\mathrm{CH}-5000$ Aarau \\ Switzerland \\ maria.cattaneo@skbf-csre.ch \\ Guido Schwerdt \\ Department of Economics \\ University of Konstanz \\ P.O. Box 133 \\ D-78457 Konstanz \\ Germany \\ guido.schwerdt@uni-konstanz.de \\ and CESifo, IZA and ROA \\ Ludger Woessmann \\ University of Munich \\ ifo Institut \\ Poschingerstr. 5 \\ D-81679 München \\ Germany \\ woessmann@ifo.de \\ and CESifo and IZA
}

\author{
Philipp Lergetporer \\ ifo Institut \\ Poschingerstr. 5 \\ D-81679 München \\ Germany \\ lergetporer@ifo.de \\ and CESifo \\ Katharina Werner \\ ifo Institut \\ Poschingerstr. 5 \\ D-81679 München \\ Germany \\ werner.k@ifo.de
}

\author{
Stefan C. Wolter \\ University of Bern \\ Swiss Coordination Centre for Research in \\ Education \\ Entfelderstrasse 61 \\ $\mathrm{CH}-5000$ Aarau \\ Switzerland \\ stefan.wolter@vwi.unibe.ch \\ and CESifo and IZA
}

\footnotetext{
* We would like to dedicate this paper to Heinrich Ursprung-which seems only fitting for a political-economy paper (his field of interest) on Switzerland (where he comes from) in comparison to Germany (where he works today) and the United States (where he worked for some years). We thank participants at the conference in honor of Heinrich Ursprung in Konstanz in September 2019 for constructive feedback and discussion. Maria Cattaneo and Stefan Wolter gratefully acknowledge the financial support given by the State Secretariat for Education, Research and Innovation, through the Leading House on Economics of Education at the Universities of Zurich and Berne. The work by Lergetporer, Werner, and Woessmann was kindly supported by the Leibniz Competition (SAW2014-ifo-2) and the German Science Foundation (CRC TRR 190).
} 


\section{Introduction}

Educational policy is one of the few domains of state action that is mainly determined nationally or even regionally and has so far successfully evaded attempts of international cooperation. Implementation of international cooperation is currently limited to the higher education sector, where the Bologna Reform in 48 mostly European countries has been a step towards a common higher education area. However, coordination of policy at the compulsory education level and cooperation between countries or groups of countries on different continents or even between developed and developing countries are largely lacking. Certainly, international comparative tests of student performance (e.g., PISA), adult competences tests (PIAAC), and teacher surveys (e.g., TALIS) have induced some implicit pressure on countries’ education systems. But while the definition of basic competences and the measurement of achievement are coordinated by organizations such as the OECD, this has in no way led to coordinated policies in the development and reform of education systems.

Although international benchmarking studies and best-practice analyses would provide insights for increased international cooperation and coordination, education policy continues to have a national character and hardly adopts impulses from abroad. Different arguments have been put forward to explain this lack of international cooperation and coordination. Some argue that knowledge is not transferrable from one country to another, so that any international cooperation is unnecessary from the outset. A host of examples of successful knowledge transfer around the globe puts this argument into question. A second argument is that educational systems have grown historically and reflect the fundamentally different cultures of the people living in the countries concerned. Relatedly, a third argument is that differences in citizens' policy preferences across countries make the implementation of coordinated education policies politically infeasible. This is the argument we address empirically in this paper.

Specifically, focusing on the three OECD countries Germany, Switzerland, and the United States, we test empirically whether citizens’ preferences for key education policies - the level of school spending, teacher salaries, and the allocation of resources in the education production process - differ systematically across these countries. Going beyond the description of these preferences, we investigate whether randomized information provision equalizes citizens' preferences across countries. 
Recent evidence on transatlantic differences in policy preferences for education by Lergetporer et al. (2018) suggests that such preferences might be rather universal. In particular, they show that while citizens in the U.S. and Germany underestimate current spending levels, they respond quite similarly to the provision of information on education spending. However, this similarity in preferences for education spending may not generalize to other policy or cultural contexts beyond the two countries.

This paper extends the available international evidence on preferences for education policies by presenting results from a large-scale representative public opinion survey on education in Switzerland. The Swiss survey was conducted online in 2015 and interviewed a total of 6,262 participants aged 18 years and older. Within the survey, we implemented three randomized experiments on how the provision of information affects support for education spending. These survey experiments were coordinated with the German and U.S. opinion surveys analyzed in Lergetporer et al. (2018) to provide comparative evidence across the three countries.

The analysis of Swiss policy preferences adds insightful evidence on an education and political system with important similarities and differences to the German and U.S. systems. In the political system, direct democracy plays a much more important role in Switzerland than in the other two countries, with important implications for information effects on preferences across countries. By contrast, the federalist system with delegation of decision power to the States, Länder, and Cantons is an important feature of education policy-making in all three countries. The Swiss vocational education system is similar to the German system but not to the U.S.. Moreover, public education finance in Switzerland differs in a number of ways from public education finance in the U.S. and Germany. Among others, Switzerland has high overall spending levels (similar to the U.S. but higher than Germany) coupled with high teacher salaries (similar to Germany but higher than the U.S.). As such, it is interesting to test whether previous results found for the other two countries extend to the Swiss context.

Our results show that baseline support for increased education spending is somewhat lower in Switzerland than in Germany and the United States. In the control group that did not receive any information, 54 percent of Swiss survey participants favor increases in government funding for public schools. The first survey experiment shows, however, that informing respondents about the current level of annual public education spending per student does away with this majority and reduces support by 14 percentage points (or 26 percent relative to the control 
mean). The information treatment brings the level of support in Switzerland much more in line with the U.S. and Germany.

Our second survey experiment examines preferences for increases in teacher salaries. Despite relatively high teacher salaries in Switzerland compared to the other countries, 27 percent of respondents in the uninformed control group are in favor of increasing teacher salaries in the future. However, when respondents are informed about current salary levels, the share who support increases in teacher salaries falls by 8 percentage points (or about 30 percent relative to the control mean). This pattern is similar to Germany but at a much lower level than the U.S., where current teacher salary levels are also much lower.

These results are robust to a series of sensitivity checks. Findings by Lergetporer et al. (2018) suggest that the effect of providing information on policy preferences reflects genuine effects of being better informed, rather than effects of being primed to think about monetary values. Extending this analysis, we show that the specific framing of the spending information has no impact on the estimated effects. Results are almost identical when the information treatment refers to annual, total, or relative spending. Moreover, consistent with previous work, we find little evidence of heterogeneous treatment effects across population subgroups defined by gender, age, education, income, employment, and parental and minority status. This suggests that our results hold for the population at large instead of being driven by a particularly large effect for a specific subgroup.

Our third experiment examines how preferences for specific categories of education spending react to the provision of information on the tradeoffs involved when choosing among them. When asked how best to allocate additional education spending, respondents' preferences shift away from class-size reductions towards alternative spending categories-teacher salaries and materials such as new books and technology—when participants are informed about the relative costs of the different spending categories.

Overall, comparison with results for the U.S. and Germany reveals that public preferences are indeed largely similar when the role of status-quo and information are taken into account. Interestingly, the reduction in support for more education spending due to information provision is very similar in relative terms (27-29 percent) in all three countries, whereas differences in treatment effects are somewhat larger for increases in teacher salaries (28-41 percent). With information about actual spending levels, the differences across countries in the overall support 
for the two reform proposals become smaller, and the remaining differences are consistent with differences in current spending and salary levels across the three countries. In light of these results, our evidence provides little support for the claim that substantial cross-country differences in preferences for education policies should prevent the possibility of international policy cooperation in this area.

This paper extends the comparative study of preferences for education spending in Germany and the U.S. in Lergetporer et al. (2018) with representative experimental evidence from Switzerland. Thereby, it contributes to several strands of the economics literature. First, it adds to the comparative political economy literature that studies cross-country differences in the public's policy preferences (e.g., Alesina and Angeletos (2005), Alesina, Di Tella, and MacCulloch (2004), Alesina, Glaeser, and Sacerdote (2001), Alesina, Glaeser, and Sacerdote (2006)). While these papers focus on areas such as redistributive policies, attitudes towards the welfare state, and working hours, we advance this descriptive literature towards the domain of public preferences for education spending.

Second, we contribute to the recent experimental literature that studies the effects of information provision on policy preferences in large-scale surveys (e.g., Cruces, Perez-Truglia and Tetaz (2013) and Kuziemko et al. (2015) on preferences for redistribution, Roth, Settele, and Wohlfart (2019) on the demand for government spending, Haaland and Roth (2017) on preferences for immigration policies, and Lergetporer, Werner, and Woessmann (2018) and Lergetporer and Woessmann (2019) for preferences for education policies). Nearly all papers in this literature are single-country studies, and only a handful conduct parallel survey experiments in different countries (e.g., Grigorieff, Roth and Ubfal (2016) on attitudes towards immigration and Bublitz (2016) and Alesina, Stantcheva, and Teso (2018) on preferences for redistribution). Thus, our parallel survey experiments in three countries add to the small set of experimental cross-country studies.

More generally, our paper complements the theoretical literature on the political economy of education spending (e.g., Glomm, Ravikumar, and Schiopu (2011)). The finding that information consistently reduces public support for education spending in the three countries we investigate suggests that downward-biased perceptions of spending levels is a rather universal phenomenon. Incorporating voters' misperceptions could therefore constitute a meaningful extension of existing political-economy models. 
The remainder of the paper is structured as follows. Section 2 provides institutional and theoretical background. Section 3 introduces the data and experimental design. Section 4 reports our main results concerning the effect of information provision on support for education spending and teacher salaries in Switzerland and provides a comparison with the U.S. and German results presented in Lergetporer et al. (2018). Section 5 investigates the role of information framing by reporting evidence of heterogeneous treatment effects by the type of spending information provided. Section 6 examines the effects of highlighting the tradeoffs between different spending categories on preferences. Section 7 concludes.

\section{Background}

We start by providing some background on the education systems in the three countries and displaying a brief theoretical framework that guides our interpretation of the information experiments.

\subsection{Background on the Education Systems in the three Countries}

Similar to Germany and the U.S., education is the third largest category of government expenditure in Switzerland (see OECD (2015), p. 73). The vast majority of students in each of the three countries is enrolled in public schools. Private school enrollment is low in all three countries. In Germany, it is 4 percent in primary school, 9 percent in lower secondary, and 8 percent in upper secondary school. In Switzerland, these figures are only slightly larger with 5 percent private school enrollment in primary school, 8 percent in lower secondary, and 13 percent in upper secondary school. For the U.S., the share of students who attend a private school is 8 percent from primary through to upper secondary school (OECD (2014), p. 416). Moreover, in all three countries the federal government plays a small role in education governance, which is reflected in relatively low contributions of the federal government to education finance. In 2011, the federal government contributed 14 percent of total funding in the U.S., 11 percent in Germany, and only 3 percent in Switzerland (OECD (2014), p. 259).

The American, German, and Swiss education systems, however, also differ in a number of important respects. For example, while only 35 percent of funding for American schools (in 2011) comes from the states, this share is 63 percent in Switzerland and 72 percent in Germany, underscoring the dominant role of the Cantons and Länder in education policy in these two countries. In the U.S., 51 percent of funding comes from the local level, compared to 34 percent 
in Switzerland and 17 percent in Germany, giving local school boards a larger role in education governance in some contexts than in others.

Spending levels also differ between the countries. According to OECD estimates, spending for primary education is 70 percent higher in Switzerland and 45 percent higher in the U.S. than in Germany, and 55 and 24 percent higher for Switzerland and the U.S. respectively for secondary education (OECD (2014), p. 215). In dollar terms, while Switzerland spent \$12,907 per student in primary education and $\$ 15,891$ in secondary education in 2011, the U.S. spent $\$ 10,958$ and $\$ 12,731$, respectively. Expenditures in Germany were at $\$ 7,579$ and $\$ 10,275$, respectively. ${ }^{1}$ Public expenditure on non-tertiary education accounts for 10.8 percent of total public expenditure in Switzerland, 9.2 percent in the U.S., and 6.7 percent in Germany (OECD (2014), p. 257).

In Switzerland, the higher overall education spending level (compared to Germany) is reflected in higher average teacher salaries. This is in contrast to the U.S., where teacher salaries are substantially lower than in Germany or Switzerland (OECD (2014), p. 467-471). In primary school, the average annual statutory salary of teachers (after 10 years of experience) is 36 and 33 percent higher in Switzerland $(\$ 61,279)$ and in Germany $(\$ 59,795)$ respectively than in the U.S. $(\$ 44,995)$. Difference are even more pronounced in secondary school, where Swiss and German teachers earn 60 and 48 percent more, respectively, than U.S. teachers at the lower secondary level and 81 and 55 percent more at the upper secondary level. ${ }^{2}$

Average class sizes in the three countries are quite similar in primary school with 21 students in Germany and in the U.S. and 19 students in Switzerland. Average class sizes in lower secondary school are substantially smaller in Switzerland (19 students) compared to Germany (24 students) and the U.S. (27 students) (OECD (2014), p. 450). Despite these differences, the total share of current education spending devoted to staff compensation is high in all three countries, with 81 percent in Germany and in the U.S. and 84 percent in Switzerland.

${ }^{1}$ These numbers correspond to 3.7 percent of GDP in the U.S., 3.0 percent of GDP in Germany, and 4 percent of GDP in Switzerland (OECD (2014), p. 230).

${ }^{2}$ Comparing teacher salaries to the earnings of other workers with a tertiary education yields a similar picture: Compared to other college-educated workers, teachers at the primary, lower secondary, and upper secondary levels, respectively, earn 88, 97, and 105 percent in Germany, 89, 104, and 114 percent in Switzerland, but only 67, 68, and 70 percent in the U.S. 


\subsection{Theoretical Framework on Information and Preferences for Education Spending}

To facilitate the interpretation of the results of our information experiments, we briefly describe here the core aspects of the theoretical framework presented in Lergetporer et al. (2018). ${ }^{3}$ Their simple theoretical framework rests on a standard preference model, so that preferences can be represented by indifference curves for bundles of two policies (spending on public education and other categories of government spending) between which a voter is indifferent. The analysis refers to the preferences of the median voter in a given country, where the distribution of preferences around that median voter means that changes in the preferred spending trajectories for this representative agent will ultimately translate into changes in the share of people in the country supporting spending increases or decreases.

The model rests on two assumptions about the median individual's knowledge and preferences which are supported by the evidence presented in Lergetporer et al. (2018) as well as by evidence from our survey data for Switzerland presented below. First, the individual underestimates current levels of spending and teacher salaries. Second, what the individual perceives to be the current levels of spending and salaries in the absence of further information are below her personal optimal levels. Thus, she prefers spending and salaries to increase.

In this framework, the effect of treatments that inform the individual about current levels of education spending can be graphically represented in a simple two-dimensional graph. In Figure $1, E_{u}$ represents the individual's estimate of the current level of education spending, while her optimal policy choice is given by $E_{u}{ }^{*}$, indicating that she favors a large increase in education spending ( $\Delta$ uninformed). If the person now is informed that the actual education spending level is in fact at $E_{i}$, her optimal policy choice would be $E_{i}^{*}$, and support for increasing education spending declines ( $\Delta$ informed $<\Delta$ uninformed). $E_{i}{ }^{*}$ lies to the left of $E_{u}{ }^{*}$ projected onto the new budget line with constant levels of other spending. The intuition is that the informed individual is equivalent to an uninformed individual who received a budget increase and spent it all on education. Since under standard preferences she prefers to spend some of this increase on other items, the new allocation reduces her relative demand for additional education spending. Thus, in a setting where individuals underestimate education spending levels and have a preference for increased education spending, one would expect that informing about education spending levels

\footnotetext{
${ }^{3}$ For further details on the model, see Appendix A of Lergetporer et al. (2018).
} 
would reduce support for spending increases. Changing the axes in Figure 1 to represent teacher salaries (rather than overall education spending) vs. other spending (inside or outside education), the analysis predicts that providing information about teacher salary levels reduces support for salary increases. ${ }^{4}$

In light of the differences in education finance across the three countries discussed above, this theoretical framework leads to two hypotheses regarding the overall support for education spending and teacher salary increases in Switzerland. First, all else equal, we expect to see lower support for spending increases, as well as smaller absolute information treatment effects, in Switzerland than in Germany. As spending levels in Switzerland are similar to the levels in the U.S., we expect to see results for educational spending in Switzerland being more similar to the U.S. results. Second, all else equal, we expect to see support for teacher-salary increases and absolute information treatment effects in Switzerland being more similar to the results for Germany, but smaller support for salary increases as well as smaller information treatment effects than in the U.S., where teacher salaries are much lower.

\section{Data and Methods}

Our empirical investigation draws on three randomized survey experiments embedded in a representative survey of public opinion on education policy in Switzerland that we conducted online in 2015. These survey experiments were coordinated with the German and U.S. opinion surveys analyzed in Lergetporer et al. (2018). Below we provide details on the Swiss survey and the information experiments within this survey. For details on the German and U.S. opinion surveys see the discussion in Lergetporer et al. (2018).

\subsection{The 2015 Public Opinion Survey on Education in Switzerland}

The survey of public opinion on education was conducted by the LINK Institute in Switzerland between June and July 2015 on behalf of the University of Bern (as part of the Swiss

\footnotetext{
${ }^{4}$ Analyzing the provision of information on a single budget item like education spending is useful in illustrating the potential consequences of transparency policies focused on this area. One should be cautious, however, in using such partial analysis to draw conclusions about how spending levels would need to change to better align with citizens' preferences. To the extent that respondents are also uninformed about other areas of public spending, the analysis does not necessarily reveal the optimality of policy choices, and providing information on education spending may also affect beliefs about spending levels on other items.
} 
Leading House on the Economics of Education). ${ }^{5}$ The survey was carried out online. A total of 6,262 language-assimilated people from the three language regions (German, French, and Ticino) aged between 18 and 74 were interviewed. The random sample was drawn via the LINK Internet Panel with over 130,000 actively recruited persons, who had been selected by phone surveys through landline and randomly generated mobile phone numbers.

Representativeness is a crucial aspect in the framework of political economy theories such as median voter models. To ensure the representativeness of the survey sample for the Swiss population, official statistics were used to establish quotas for age, gender, region, and education. As our focus is on individuals who are eligible to vote in Switzerland, we further exclude nonSwiss nationals from the sample. This reduces the total number of observations in the sample to 5,934 adults. Moreover, in our empirical analysis we employ survey weights throughout to ensure the sample's representativeness with respect to the national adult population. ${ }^{6}$

Overall, the survey comprised 28 questions on education policy. These include the three survey experiments on education spending which were coordinated with the U.S. and the German survey used in Lergetporer et al. (2018). Within the survey experiments, the maximum number of different treatment conditions was four.

\subsection{Experimental Design}

In the Swiss survey, we replicate and extend three randomized survey experiments from Lergetporer et al. (2018). That means we provide randomly chosen subgroups of respondents with different types of factual spending information for Switzerland before eliciting their preferences for education spending in the same way as in the uninformed control group. We independently randomize these information treatments across the three survey experiments. The randomization allows us to identify the causal effect of providing the specific information on the public's preferences for education spending.

Our first experiment focuses on the preferred level of public school spending. To elicit preferences for overall increases in spending, the uninformed control group was asked whether they support increases or decreases in national government funding (see Appendix A for precise wording). Five answer categories are available to respondents: greatly increase, increase, stay

\footnotetext{
${ }^{5}$ Further information on the LINK Institute can be found at https://www.link.ch/.

${ }^{6}$ Grewenig et al. (2018) show that for survey items on education topics, appropriate weighting of online-only samples closely matches results obtained for the entire population (onliners and offliners).
} 
about the same, decrease, or greatly decrease. In total, there are three informed treatment groups. One treatment group was informed that the actual level of national spending per student is 20,000 CHF in Switzerland. This treatment replicates the information treatment used in the U.S. and Germany in Lergetporer et al. (2018). ${ }^{7}$

To investigate whether the precise presentation of information changes the perception of respondents, we extend the experimental design by including two additional treatment groups in the Swiss survey. These two groups also received information on the actual level of national spending per student, but in these treatments the total public costs per student are not expressed as annual spending. In one treatment, respondents were informed that the total level of school spending per student for the duration of 9 years of compulsory schooling is 180,000 CHF. The other treatment informed respondents that the average spending per student for the duration of compulsory schooling was equivalent to 16 years of tax revenues of an average income earner in Switzerland. These additional treatments allow us to investigate whether the nature or the form of presentation of the information affects the impact of the information on stated preferences, which has important implications for the interpretation of possible treatment effects. We discuss these results and the possibility of framing effects in section 5.

In our second parallel survey experiment, we ask respondents about their support for increases or decreases in the salaries of public-school teachers. While the uninformed control group is asked to answer the respective survey question without additional information, the treatment group receives information on the actual current level of teacher salaries in Switzerland. More precisely, respondents are informed that a teacher in Switzerland with more than 10 years of work experience receives an annual gross salary of 100,000 CHF. This treatment is directly comparable to the information treatment on teacher salaries in the U.S. and Germany in Lergetporer et al. (2018).

In addition to this information treatment on absolute teacher salaries, we again implement an additional information treatment in the Swiss survey that presents information on teacher salaries in relative terms. More precisely, the treatment informs respondents that a teacher in Switzerland with more than 10 years of work experience receives a salary that is 20 percent above the

\footnotetext{
${ }^{7}$ The treatment group in Lergetporer et al. (2018) was informed about the actual level of spending per student in their district in the U.S. (\$12,400 on average across the sample) or nationally in Germany $(€ 6,400)$.
} 
average salary level in Switzerland. Results for this treatment effect are also discussed in section 5.

Our third parallel survey experiment examines preferences for different categories of education spending. ${ }^{8}$ In this experiment, the control group is asked whether a planned increase in government spending should go towards class-size reductions, teacher salary increases, or new books and technologies. Before choosing one of these three options, the treatment group is informed that in Switzerland, reducing average class sizes by 3 students would cost roughly the same amount as increasing teacher salaries by 15 percent or buying 20,000 CHF in new books and technologies for each class every year. While the experimental design of this experiment is directly comparable to Lergetporer et al. (2018), the treatment information differs to reflect the differences in cost structures across countries.

We report our results both with and without the following set of control variables: gender, parental and employment status, income, ${ }^{9}$ age (measured in the four categories 18-34, 35-49, 5064, and 65+), education (measured in the three categories less than high school, high school but no B.A., and B.A. degree or higher), and minority status. The minority status variable, indicating whether at least one parent was not born in Switzerland, serves as a rough proxy for individuals with migration background.

For the control group and the main treatment group in the first two experiments, Table 1 shows that the samples are overall well balanced across the treatment conditions in terms of these observable characteristics. Only two small differences (out of 30) are statistically significant. Moreover, joint $F$-tests in regressions of the treatment dummies on all covariates are statistically insignificant. The same is true for the other treatment conditions of these experiments, as well as for the third experiment. ${ }^{10}$

\footnotetext{
${ }^{8}$ Since each respondent participated in all three independently randomized experiments, information provision in earlier experiments might affect preferences or treatment effects in later experiments. In additional analyses, we find that our main results are not driven by such cross-treatment effects (not shown).

${ }^{9}$ Income is reported in three categories. Low refers to a monthly gross income of below 6,000 CHF, while high refers to a monthly gross income of above 10,000 CHF. These two thresholds correspond roughly to the first and third quartile of the income distribution in Switzerland. In all regressions with control variables, we also include a fourth income categories, indicating observations with missing income information in the Swiss data.

10 The additional balancing tables are available from the authors upon request.
} 


\section{The Effect of Information Provision on Support for Education Spending and Teacher Salaries in the three Countries}

We start the presentation of our results by showing the experimental estimates of the effect of information provision on support for increases in education spending and in teacher salaries. In both cases, respondents in the treatment and control conditions were asked to indicate their preferences on a five-point scale ranging from "greatly decrease” to "greatly increase,” with the middle category indicating that spending or salary levels should "stay about the same.” Our main estimations of treatment effects are based on linear probability models where the top two and bottom three response options are collapsed to create a binary indicator of support for a spending or salary increase. We also show results in which the outcome is defined as the probability of support for decreased spending or salaries (collapsing the top three and bottom two answer categories).

\subsection{Preferences for Education Spending}

In the control group that did not receive any specific information, 54 percent of the Swiss population favors government funding for public schools to increase or greatly increase (Figure 2). This is slightly lower than the levels of support of 60 percent in the U.S. and 71 percent in Germany reported in Lergetporer et al. (2018). The lower support for increased spending in Switzerland is consistent with the fact that spending levels are currently higher in Switzerland than in the other two countries.

The first column of Table 2 shows a descriptive analysis of who supports higher spending in Switzerland. Parents and people with migration background are more in favor of spending increases, while employed people and older people are less in favor. This pattern is consistent with descriptive evidence from earlier opinion surveys on education in Switzerland which also found that elderly people have a tendency to be less willing to spend money on education (Cattaneo and Wolter (2009)).

Table 3 presents our main estimates of how the information treatment affects support for education spending. In each of the three countries, the treatment substantially reduces support for increased spending, so that the majority in favor of increased spending vanishes among those who are informed about current spending levels (see also Figure 2). The first two columns reproduce the experimental estimates for the U.S. and Germany from Lergetporer et al. (2018). 
Being informed about current spending levels reduces support for increased spending by 17 percentage points in the U.S. (column 1) and by 20 percentage points in Germany (column 2). This is equivalent to 28-29 percent of the control mean in the two countries.

In Switzerland, we find a slightly smaller absolute treatment effect of 14.4 percentage points (column 3). In the specification with control variables, the estimate is almost identical at 14.6 percentage points (column 4), indicating that randomization successfully balanced covariates across the treatment conditions. Relative to the control mean, the treatment effect in Switzerland amounts to a reduction of support of 27 percent-remarkably similar to the relative effects in the other two countries. Thus, treatment effects in relative terms are almost identical in the three countries.

Column 5 reports the same model with an indicator for support for spending decreases (rather than increases) as dependent variable. ${ }^{11}$ While the control mean of 3 percent is low, the information treatment raises support for decreased spending by 2 percentage points.

\subsection{Preferences for Teacher Salaries}

Our second survey experiment examines how the provision of information influences public support for increases of teacher salaries. Arguably, teacher salaries are a particularly interesting component of education spending for at least two reasons. First, personnel costs are typically the most important cost component in any public education system (81-84 percent in the three considered countries, see section 2.1 above). Second, given that people are likely to have clearer benchmarks drawn from their own personal experience on the appropriate level of compensation (in contrast to the relatively abstract concept of annual per-student spending levels), the effects of information provision might differ due to more precise prior beliefs on actual and preferred teacher salary levels.

In Switzerland, 27 percent of the uninformed control group support increases in teacher salaries. This share is quite similar to Germany (29 percent) but substantially lower than in the U.S. (62 percent; Figure 3). This difference is consistent with the evidence presented above that teacher salaries are substantially higher in Switzerland and Germany than in the U.S., both in absolute terms and relative to other college graduates.

\footnotetext{
${ }^{11}$ We do not show results for the residual category, which is a preference for spending to "stay about the same”.
} 
Descriptively, most of the observable individual characteristics in our data cannot predict differences in the level of support for teacher salary increases in Switzerland. The second column of Table 2 only shows that individuals with migration background are more likely to support teacher salary increases, while employed people are less likely to support increases.

Table 4 reports the results of the survey experiment examining how informing respondents about current levels of teacher salaries affects their support for salary increases (see also Figure 3). The information treatment reduces support for teacher salary increases by 24 percentage points in the U.S. (column 1) and by 12 percentage points in Germany (column 2). For Switzerland, we find a negative treatment effect of 7.4 percentage points without controls (column 3) and 7.5 percentage points with controls (column 4). Interestingly, treatment effects relative to the control mean are again quite similar in the U.S. (42 percent) and Germany (39 percent). However, in Switzerland the treatment effect is also less strong in relative terms, with an effect size of 29 percent. Thus, while the overall pattern of results is again quite similar across the three countries, the Swiss population reacts less strongly to the information on teacher salaries.

Column 5 again reports the same model with an indicator for support for teacher salary decreases (rather than increases) as dependent variable. In the uninformed control group, 10 percent of the respondents support decreases in teacher salaries. This support for decreasing teacher salaries grows by 6 percentage points (or 68 percent of the control mean) when people are informed about current salary levels in Switzerland.

\subsection{Heterogeneous Treatment Effects by Demographic Subgroups}

Table 5 reports the treatment effects of the school spending experiment and the teacher salary experiment for subgroups defined based on the following characteristics: gender, parental status, employment status, minority status, income, age, education, and political views. Interestingly, treatment effects are significant in all subgroups, and they rarely differ significantly across subgroups.

There are only few cases where treatment effects differ in a noteworthy way. This is the case for the treatment effect in the school spending experiment by gender, education, and parental status and in the salary experiment by minority status and parental status. Due to the large number of subgroup comparisons and the associated risk of false conclusions, we refrain from offering substantive interpretations of these differences. Most importantly, the heterogeneity 
analysis in Table 5 shows that the average treatment effects reported in Tables 3 and 4 are not driven by specific sociodemographic subgroups.

\section{Framing Effects: Heterogeneity by Type of Spending Information Provided}

A common concern in survey experiments with information treatments is that the estimated effects do not reflect genuine information effects, but depend on respondents having been primed to think about the topic or being affected by the way the information is framed. ${ }^{12}$ Based on elicited information of participants' prior knowledge of spending and salary levels, Lergetporer et al. (2018) present further analysis suggesting that priming effects cannot explain the estimated effects. Here, we extend this discussion by analyzing the robustness of treatment effects to different framing of the spending information.

To shed light on the importance of framing effects, we make use of our additional treatment conditions in the spending and the teacher salary experiments in Switzerland. In particular, we estimate models based on the full sample and interact the treatment indicator (informed) with indicators for the different types of spending information that the different treatment groups have received. Recall that in the school spending experiment, we randomly provide spending information in annual, total (for nine years of compulsory education), or relative terms (relative to the tax revenue over 16 years of an average income earner). In the teacher salary experiment, informed respondents randomly received the information either in terms of actual annual teacher salaries or in relative terms (relative to the average income Switzerland). In all regressions, the absolute annual spending information treatment that we analyze in Tables 3-5 serves as the baseline category.

Table 6 reports the results of this analysis. The first row shows our baseline estimates (with and without controls) of being informed about the annual level of school spending (columns 1 and 2) as well as annual teacher salaries (columns 3 and 4). The second row shows that the estimated interaction terms between being informed and the type of presentation of the information are small (between 0.0 and 1.7 percentage points) and statistically insignificantly

\footnotetext{
${ }^{12}$ A related concern are experimenter demand effects, which occur if respondents anticipate the experimenters' intentions from the treatment and adapt their answers accordingly. Mummolo and Peterson (2019) find that experimenter demand effects are largely absent in survey experiments, and de Quidt et al. (2018) provide evidence that experimenter demand effects hardly affect results of experiments on economic preferences.
} 
different from zero throughout. This implies that reporting the spending and salary information in relative terms instead of showing annual monetary values generates identical treatment effects. Similarly, row 3 of Table 6 shows that providing total spending information for 9 years of compulsory schooling instead of annual spending levels has no significant impact on the estimates.

These novel results show that the estimated effect of information on stated preferences is remarkably robust to different variations of presenting the information. Thus, we conclude that our estimated treatment effects are unlikely driven by a particular framing of the spending information, but rather reflect general information effects.

\section{Evidence on Tradeoffs between Different Spending Categories}

Our third survey experiment allows us to study support for education spending across specific spending categories. In particular, we investigate the effect of providing information on the tradeoff involved between different spending options. To shed light on this issue, we ask all respondents in the survey to suppose that the government plans to increase spending in the school system and ask them to choose one of the following three options: reducing class sizes, increasing teacher salaries, and purchasing new books and technologies. A randomly selected treatment group additionally receives information about the relative prices of the three policy options.

Figure 4 shows the results of this experiment and compares them to the findings for the U.S. and Germany. In the uninformed control group, at least a plurality of respondents in each country favors class-size reductions over the other options: 46 percent in the U.S., 64 percent in Germany, and 62 percent in Switzerland. Consistent with the second experiment, fewer Germans (4 percent) and Swiss (5 percent) than Americans (24 percent) favor teacher salary increases. Roughly one third of respondents in each country favors the purchase of new books and technologies.

The treatment group is informed that in Switzerland (Germany) [the U.S.], reducing average class sizes by 3 students would cost roughly the same amount as increasing teacher salaries by 15 (15) [13] percent or buying 20,000 CHF (€20,000) [\$10,000] in new books and technologies for each class every year before choosing one of these three options. This treatment reduces support for class-size reductions in all three countries, to 35 percent in the U.S., 48 percent in Germany, 
and 55 percent in Switzerland. While in the U.S., support mainly shifts towards increasing teacher salaries (increase to 33 percent), in Germany it mainly shifts towards buying new books and technologies (increase to 46 percent). In Switzerland, the reduction in support for class-size reductions is overall more moderate and leads to equally large increases in the support for teacher salaries ( 3 percentage-point increase to 8 percentage points) and the support for buying new books and technologies (4 percentage-point increase to 37 percentage points). While the overall pattern of preferences across the three categories in Switzerland is thus quite similar to Germany, the shift from class-size reductions to new materials induced by the information treatment is less pronounced.

In sum, support for education spending is affected not only by information on spending levels, but also by information on the tradeoffs involved between different categories of education spending. In particular, once aware of these tradeoffs, the public in the three countries expresses far less enthusiasm for class-size reductions. Overall, in this experiment treatment effects appear smaller in Switzerland than in the U.S. and Germany. However, the shift from reductions in class size as most favored option to either teacher salaries or new books and technology is again common to all three countries.

\section{Conclusions}

This paper makes two contributions. First, we provide representative evidence from a Swiss survey on how information affects public preferences for education spending. Second, we compare the preferences and responses to information provision observed in Switzerland with the patterns obtained in Germany and the U.S. using identical survey techniques.

For Switzerland, we find that support for increasing education spending declines from 54 percent to 40 percent when respondents are informed about current public education spending. Similarly, support for increasing teacher salaries declines from 27 percent in the uninformed control group to 19 percent among respondents who were informed about actual salary levels. These effects do not differ significantly across different treatments that present the information

in different forms, speaking against substantial relevance of specific framing. Finally, support for investing additional education spending in class-size reductions reduces from 62 percent to 55 percent when respondents are informed about the implicit costs of class-size reductions. 
Comparing these results for Switzerland to results of parallel survey experiments in the U.S. and Germany, two patterns emerge. First, a large share of the differences in the level of public support for increases in education spending and teacher salaries can be explained with the statusquo spending policies in the respective countries, hence not rejecting common preferences of the electorates across the three countries. In particular, consistent with differences in status-quo policies, the Swiss results on spending are more in line with the U.S. and the Swiss results on teacher salaries are more in line with Germany. Second, information treatment effects are also quite similar in the three countries, and are consistent with a simple preference model in which information induces shifts in voters' budget constraints. In particular, in all three countries majority support for overall public spending increases in education turns into a minority when people are informed about current spending levels. This similarity of information treatment effects across countries is particularly noteworthy given that the three countries' public education systems differ from each other in several important dimensions, such as funding sources and the role of direct democracy in education governance.

Our results shed light on the role of international differences in political preferences in the setting of education policy. Findings suggest that while differences in existing education policy across countries are reflected in electoral preferences for future spending, we cannot rule out similar underlying preferences across Switzerland, the U.S., and Germany. At the most basic level, our results suggest that the mechanisms that underlie public preference formation over education spending are rather universal across countries. If preferences were indeed homogenous across countries, this would have important implications for the international transferability of best-practice education policies and the potential for international cooperation. 


\section{References}

Alesina, Alberto, George-Marios Angeletos (2005). Fairness and Redistribution. American Economic Review 95 (4): 960-980.

Alesina, Alberto, Stefanie Stantcheva, Edoardo Teso (2018). Intergenerational Mobility and Support for Redistribution. American Economic Review 108 (2): 521-554.

Alesina, Alberto, Rafael Di Tella, Robert MacCulloch (2004). Inequality and Happiness: Are Europeans and Americans Different? Journal of Public Economics 88 (9-10): 2009-2042.

Alesina, Alberto, Edward Glaeser, Bruce Sacerdote (2001). Why Doesn't the United States Have a European-Style Welfare State? Brookings Papers on Economic Activity (2): 187-254.

Alesina, Alberto, Edward Glaeser, Bruce Sacerdote (2006). Work and Leisure in the United States and Europe: Why So Different? NBER Macroeconomics Annual 2005: 1-64.

Bublitz, Elisabeth (2016). Misperceptions of Income Distributions: Cross-country Evidence from a Randomized Survey Experiment. HWWI Research Paper 178.

Cattaneo, M. Alejandra, Stefan C. Wolter (2009). Are the Elderly a Threat to Educational Expenditures? European Journal of Political Economy 25: 225-236.

Cruces, Guillermo, Ricardo Perez-Truglia, Martin Tetaz (2013). Biased Perceptions of Income Distribution and Preferences for Redistribution: Evidence from a Survey Experiment. Journal of Public Economics 98: 100-112.

De Quidt, Jonathan, Johannes Haushofer, Christopher Roth (2018). Measuring and Bounding Experimenter Demand. American Economic Review 108 (11): 3266-3302.

Grewenig, Elisabeth, Philipp Lergetporer, Lisa Simon, Katharina Werner, Ludger Woessmann (2018). Can Online Surveys Represent the Entire Population? CESifo Working Paper 7222.

Grigorieff, Alexis, Christopher Roth, Diego Ubfal (2016). Does Information Change Attitudes Towards Immigrants? Representative Evidence from Survey Experiments. IZA Discussion Paper No. 10419.

Glomm, Gerhard, B. Ravikumar, Ioana C. Schiopu (2011). The Political Economy of Education Funding. In Handbook of the Economics of Education, Vol. 4, edited by Eric A. Hanushek, Stephen Machin, Ludger Woessmann. Amsterdam: North Holland: 615-680.

Haaland, Ingar, Christopher Roth (2017). Labor Market Concerns and Support for Immigration. Working Paper.

Kuziemko, Ilyana, Michael I. Norton, Emmanuel Saez, Stefanie Stantcheva (2015). How Elastic Are Preferences for Redistribution? Evidence from Randomized Survey Experiments. American Economic Review 105 (4): 1478-1508.

Lergetporer, Philipp, Guido Schwerdt, Martin R. West, Katharina Werner, Ludger Woessmann (2018). How Information Affects Support for Education Spending: Evidence from Survey Experiments in Germany and the United States. Journal of Public Economics 167: 138-157. 
Lergetporer, Philipp, Katharina Werner, Ludger Woessmann (2018). Educational Inequality and Public Policy Preferences: Evidence from Representative Survey Experiments. CESifo Working Paper 7192.

Lergetporer, Philipp, Ludger Woessmann (2019). The Political Economy of Higher Education Finance: How Information and Design Affect Public Preferences for Tuition. CESifo Working Paper 7536.

Mummolo, Jonathan, Erik Peterson (2019). Demand Effects in Survey Experiments: An Empirical Assessment. American Political Science Review 113 (2): 517-529.

OECD (2014). Education at a Glance 2014: OECD Indicators. Paris: Organisation for Economic Co-operation and Development.

OECD (2015). Government at a Glance 2015. Paris: Organisation for Economic Co-operation and Development.

OECD (2016). Personal Income Tax: All-in Average Rates by Family Type. OECD Tax Statistics. Doi: http://Dx.Doi.Org/10.1787/Data-00805-En (Accessed March 7, 2016).

Roth, Christopher, Sonja Settele, Johannes Wohlfart (2019). Beliefs About Public Debt and the Demand for Government Spending. Working Paper. 


\section{Appendix A: Wording of the Survey Questions}

\section{Support for higher education spending:}

U.S.: Uninformed [Informed]: [As it turns out, according to the most recent information available $\$\{$ value $\}$ is being spent each year per child attending public schools in your district.] Do you think that government funding for public schools in your district should increase, decrease, or stay about the same?

Germany: Uninformed [Informed]: [Die staatlichen Bildungsausgaben in Deutschland betragen im Durchschnitt jährlich 6400 Euro pro Schülerin/Schüler.] Sollten die staatlichen Ausgaben für Schulen in Deutschland Ihrer Meinung nach steigen, sinken oder unverändert bleiben?

Switzerland: Uninformed [Informed 1] / [Informed 2] / [Informed 3]: [In der Schweiz werden im Durchschnitt jährlich ca. 20`000 Franken pro Schülerin oder Schüler in der obligatorischen Schule ausgegeben.] / [In der Schweiz werden für neun Schuljahre im Durchschnitt ca. 180`000 Franken pro Schülerin oder Schüler in der obligatorischen Schule ausgegeben.] / [Um einen Schüler für die gesamte obligatorische Schulzeit zu finanzieren, braucht es die gesamten Steuererträge eines durchschnittliches Steuerzahlers über einen Zeitraum von 16 Jahren.] Sollten die staatlichen Ausgaben für Schulen (1.-9. Klasse) in der Schweiz Ihrer Meinung nach: Stark steigen, steigen, ungefähr gleich bleiben, sinken, stark sinken?

\section{Support for higher teacher salaries:}

U.S.: Uninformed [Informed]: [As it turns out, public school teachers in your state are paid an average annual salary of $\$\{$ value $\}$.] Do you think that public school teacher salaries should increase, decrease, or stay about the same?

Germany: Uninformed [Informed]: [In Deutschland verdienen vollzeitbeschäftigte Lehrerinnen und Lehrer im Durchschnitt rund 3000 Euro netto im Monat.] Was meinen Sie, sollten die Gehälter von Lehrerinnen und Lehrern in Deutschland steigen, sinken oder unverändert bleiben?

Switzerland: Uninformed [Informed 1] / [Informed 2]: [In der Schweiz verdienen Lehrerinnen und Lehrer der Primarschule nach 10 Jahren Berufserfahrung im Durchschnitt rund 100`000 Franken brutto im Jahr.] / [In der Schweiz verdienen Lehrerinnen und Lehrer der Primarschule nach 10 Jahren Berufserfahrung im Durchschnitt etwa 20\% mehr als eine durchschnittliche Arbeitnehmerin oder ein Arbeitnehmer.] Sollten die Gehälter von Lehrerinnen 
und Lehrern Ihrer Meinung nach: Stark steigen, steigen, ungefähr gleich bleiben, sinken, stark sinken.

\section{Support for different spending categories:}

U.S.: Uninformed: Suppose the government plans to increase spending in the school system. Which one of the following options do you favor? Reducing class sizes - Increasing teacher salaries - Purchasing new books and technologies. Informed: Suppose the government plans to increase spending in the school system. Reducing average class sizes by 3 students would cost roughly the same amount as increasing teacher salaries by 13 percent or buying $\$ 10,000$ in new books and technologies for each class every year. Among these options, which do you favor? Reducing class sizes by 3 students - Increasing teacher salaries by 13 percent - Purchasing $\$ 10,000$ in new books and technologies for each class every year.

Germany: Uninformed: Stellen Sie sich vor, die Regierung plant, die Ausgaben für das Schulsystem zu erhöhen. Für welche der folgenden Möglichkeiten sind Sie? Schulklassen verkleinern - Lehrergehälter erhöhen - Neue Schulbücher, Computer und andere Lehrmittel anschaffen. Informed: Stellen Sie sich vor, die Regierung plant, die Ausgaben für das Schulsystem zu erhöhen. Die Schulklassen um drei Schülerinnen/Schüler zu verkleinern, würde in etwa so viel kosten, wie die Lehrergehälter um 15 Prozent zu erhöhen oder neue Lehrmittel im Wert von jährlich 20000 Euro für jede Klasse anzuschaffen. Für welche dieser Möglichkeiten sind Sie? Schulklassen um 3 Schüler verkleinern - Lehrergehälter um 15 Prozent erhöhen Neue Schulbücher, Computer und andere Lehrmittel im Wert von jährlich 20.000 Euro für jede Klasse anschaffen.

Switzerland: Uninformed: Stellen Sie sich vor, die Regierung plant, die Ausgaben für das Schulsystem zu erhöhen. Für welche der folgenden Möglichkeiten sind Sie? Schulklassen verkleinern - Lehrergehälter erhöhen - Neue Schulbücher, Computer und andere Lehrmittel anschaffen. Informed: Stellen Sie sich vor, die Regierung plant, die Ausgaben für das Schulsystem zu erhöhen. Die Schulklassen um drei Schülerinnen/Schüler zu verkleinern würde in etwa so viel kosten, wie die Lehrergehälter um 15 Prozent zu erhöhen oder neue Lehrmittel im Wert von jährlich 20.000 CHF für jede Klasse anzuschaffen. Für welche dieser Möglichkeiten sind Sie? Schulklassen verkleinern - Lehrergehälter erhöhen - Neue Schulbücher, Computer und andere Lehrmittel anschaffen. 
Figure 1: The effect of status information on support for policy change

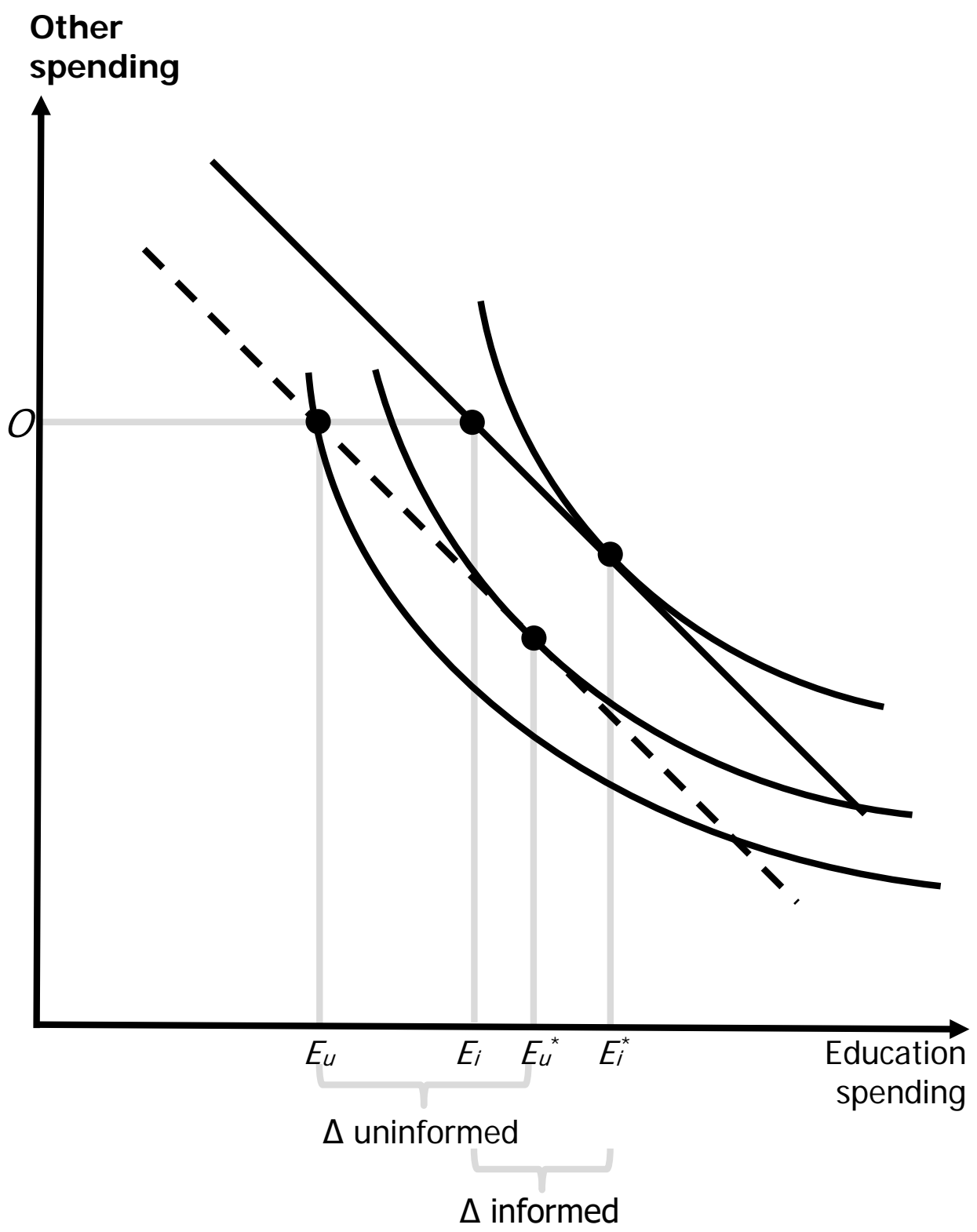

Notes: $E_{u}=$ education spending (uninformed); $E_{i}=$ education spending (informed); $E_{u}^{*}=$ optimal education spending (uninformed); $E_{i}^{*}=$ optimal education spending (informed); $O=$ other spending. Source: Lergetporer et al. (2018). 
Figure 2: The effect of information about current spending levels on support for higher spending

80

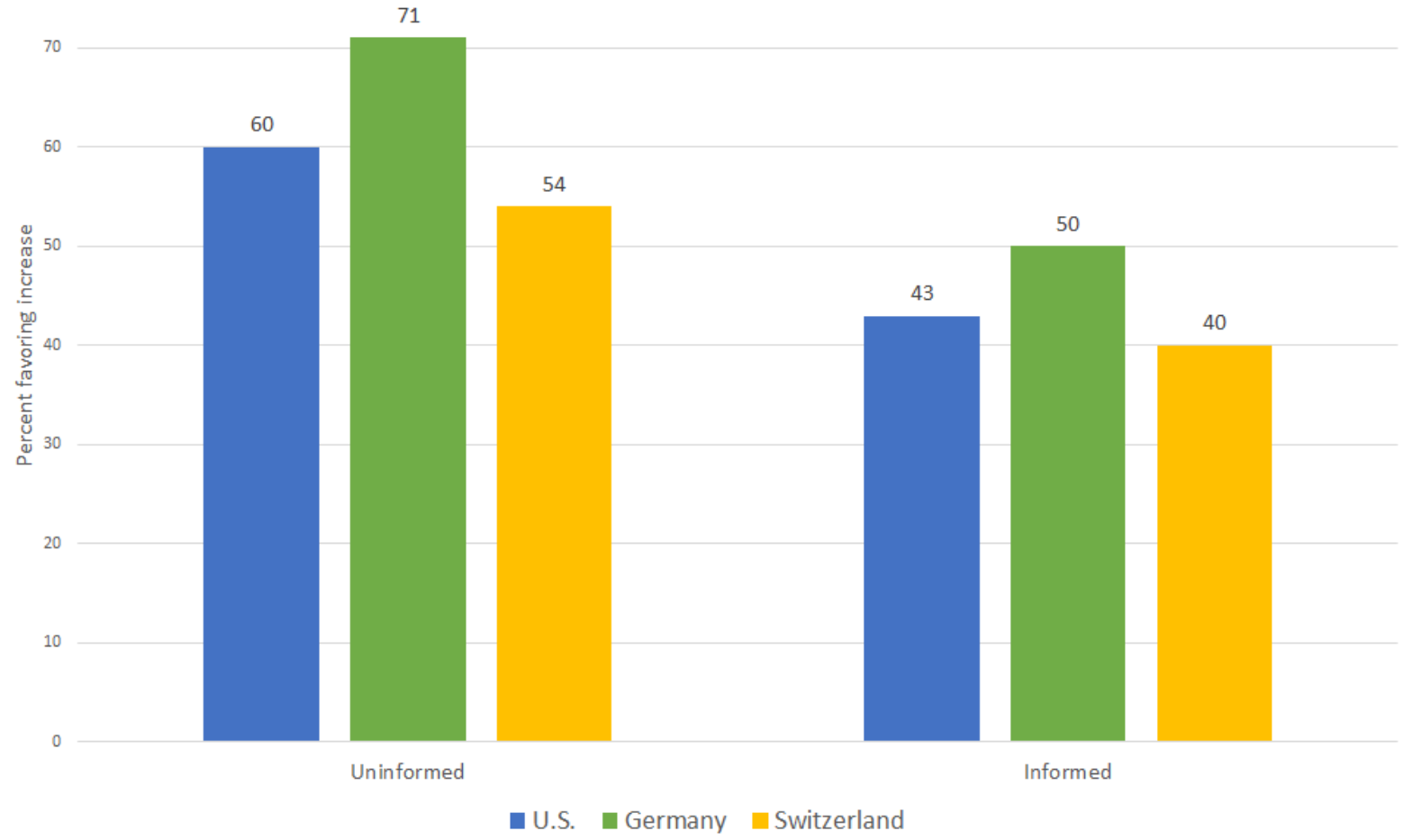

Notes: Share of respondents who favor government funding for public schools to either "greatly increase" or "increase"; other categories are "stay about the same", "decrease", and "greatly decrease". Two randomized experimental groups. The control group (Uninformed) did not receive further information. The treatment group (Informed) was informed about current spending levels. Source: The 2015 public opinion survey on education in Switzerland and Lergetporer et al. (2018). 
Figure 3: The effect of information about current salary levels on support for higher teacher salaries

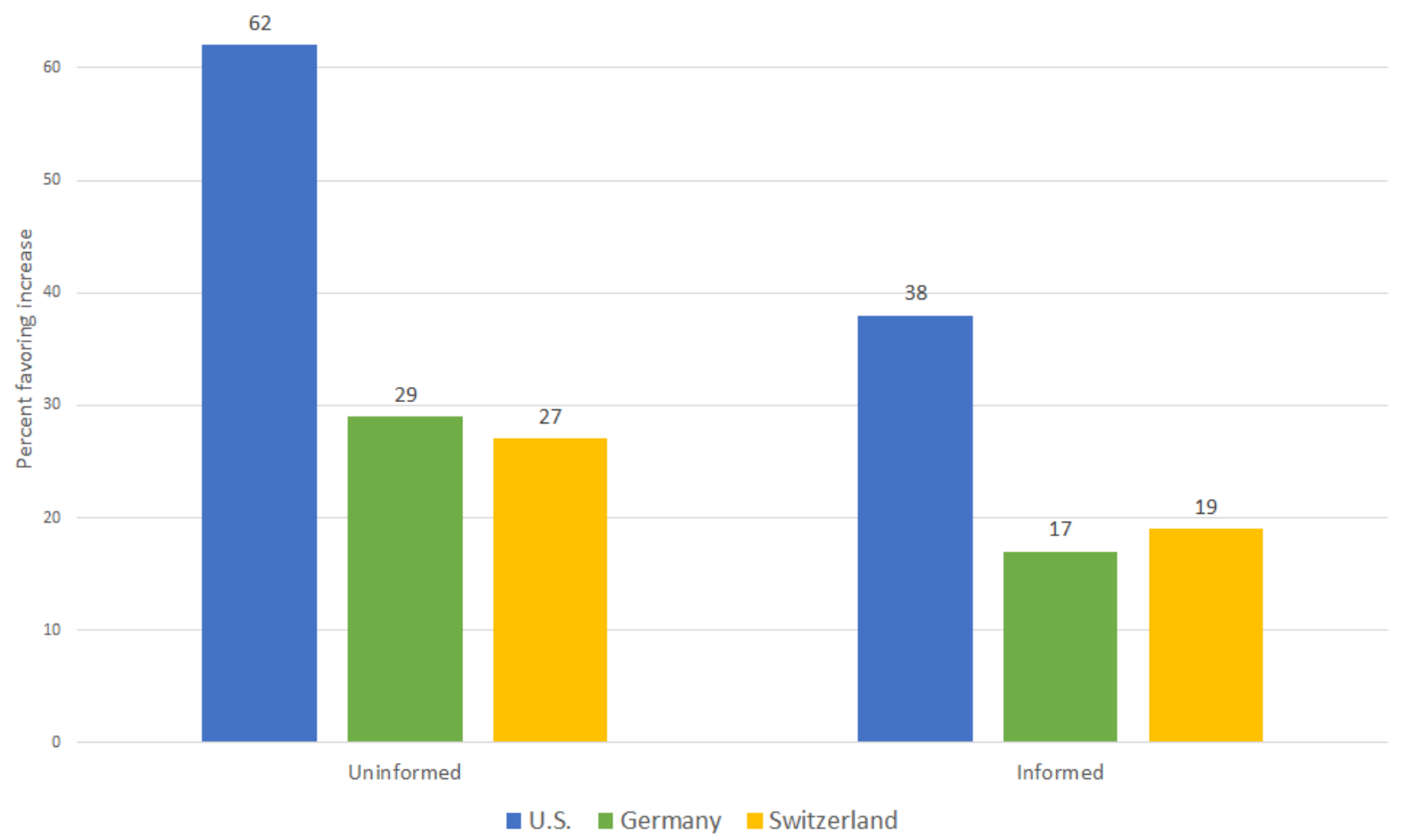

Notes: Share of respondents who favor teacher salaries to either "greatly increase" or "increase"; other categories are "stay about the same", "decrease", and "greatly decrease". Two randomized experimental groups. The control group (Uninformed) did not receive further information. The treatment group (Informed) was informed about current teacher salary levels. Source: The 2015 public opinion survey on education in Switzerland and Lergetporer et al. (2018). 
Figure 4: Support for spending on smaller classes, higher salaries, and teaching material

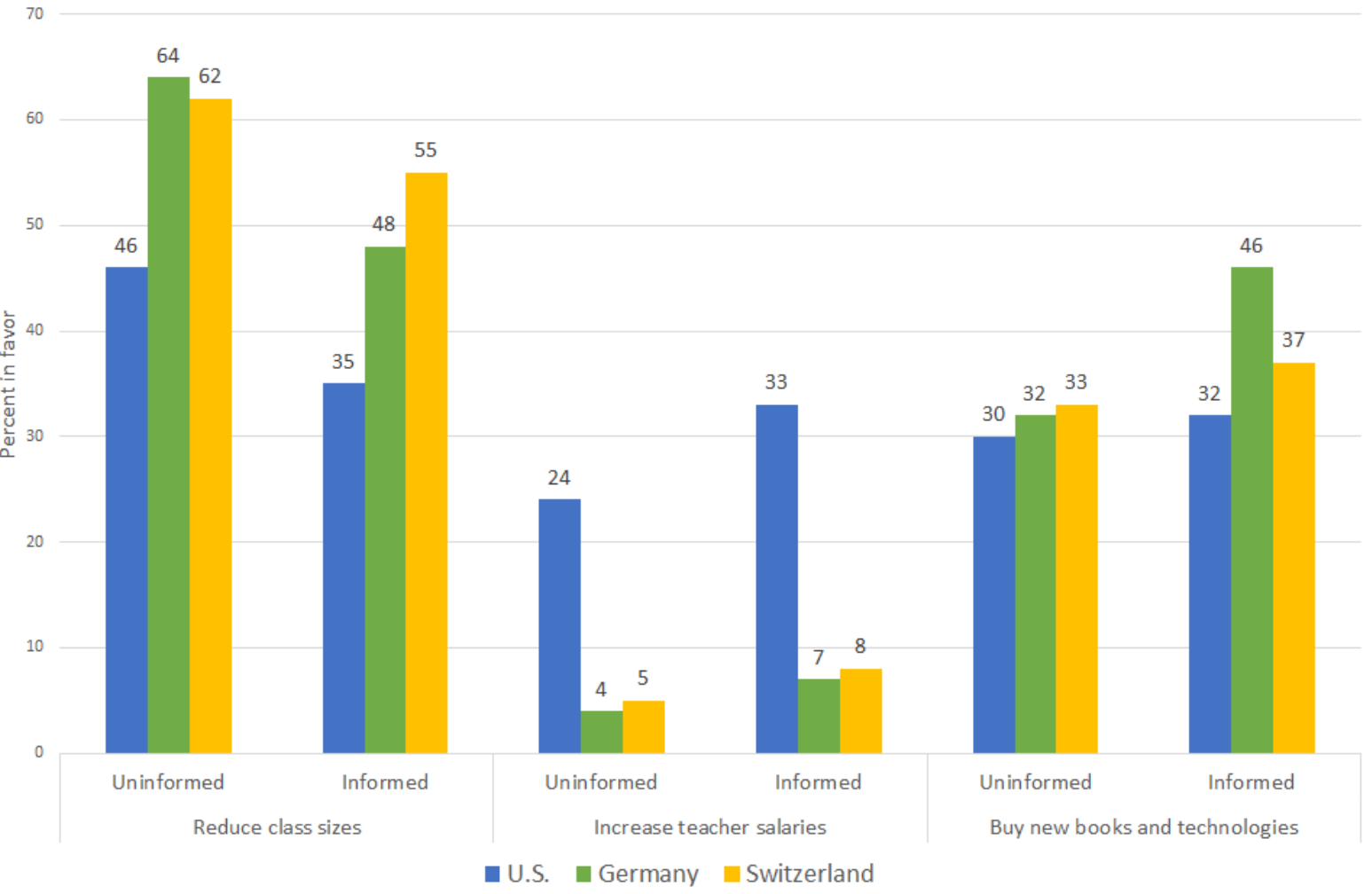

Note: Share of respondents favoring the specific spending option over the other two options. Two randomized experimental groups. Control group (Uninformed) did not receive further information. Treatment group (Informed) was informed that reducing average class sizes by 3 students would cost roughly the same amount as increasing teacher salaries by 13 (15) [15] percent or buying $\$ 10,000$ (EUR 20,000) [20,000 $\mathrm{CHF}$ ] in new books and technologies for each class every year in the U.S. (Germany) [Switzerland]. See Appendix A for wording of the question in the three countries. Source: The 2015 public opinion survey on education in Switzerland and Lergetporer et al. (2018). 
Table 1: Descriptive statistics and balance across treatment conditions

\begin{tabular}{|c|c|c|c|c|c|c|}
\hline & \multicolumn{3}{|c|}{ School spending experiment } & \multicolumn{3}{|c|}{ Teacher salary experiment } \\
\hline & $\begin{array}{c}\text { Uninformed } \\
\text { (1) }\end{array}$ & $\begin{array}{l}\text { Informed } \\
(2)\end{array}$ & $\begin{array}{c}\text { Difference } \\
(3)\end{array}$ & $\begin{array}{l}\text { Uninformed } \\
\text { (4) }\end{array}$ & $\begin{array}{l}\text { Informed } \\
(5)\end{array}$ & $\begin{array}{c}\text { Difference } \\
\quad(6)\end{array}$ \\
\hline Female & 0.511 & 0.492 & -0.019 & 0.513 & 0.504 & -0.009 \\
\hline Parent & 0.622 & 0.606 & -0.016 & 0.612 & 0.628 & 0.016 \\
\hline Employed & 0.574 & 0.582 & 0.009 & 0.586 & 0.587 & 0.002 \\
\hline Minority & 0.191 & 0.219 & $0.028 * *$ & 0.191 & 0.203 & 0.012 \\
\hline \multicolumn{7}{|l|}{ Income } \\
\hline low & 0.261 & 0.270 & 0.009 & 0.279 & 0.278 & -0.001 \\
\hline medium & 0.336 & 0.302 & $-0.034 *$ & 0.316 & 0.329 & 0.014 \\
\hline high & 0.180 & 0.196 & 0.016 & 0.182 & 0.171 & -0.012 \\
\hline missing & 0.224 & 0.232 & 0.008 & 0.223 & 0.222 & -0.001 \\
\hline \multicolumn{7}{|l|}{ Age } \\
\hline $16-34$ & 0.249 & 0.268 & 0.019 & 0.253 & 0.238 & -0.015 \\
\hline $35-49$ & 0.330 & 0.327 & -0.003 & 0.344 & 0.348 & 0.004 \\
\hline $50-64$ & 0.260 & 0.264 & 0.004 & 0.241 & 0.261 & 0.020 \\
\hline $65+$ & 0.161 & 0.141 & -0.021 & 0.162 & 0.153 & -0.008 \\
\hline \multicolumn{7}{|l|}{ Education } \\
\hline Less than high school & 0.168 & 0.171 & 0.003 & 0.178 & 0.176 & -0.003 \\
\hline High school but no B.A. & 0.512 & 0.532 & 0.020 & 0.522 & 0.512 & -0.010 \\
\hline B.A. degree or higher & 0.320 & 0.298 & -0.023 & 0.300 & 0.313 & 0.013 \\
\hline Observations & 1,495 & 1,477 & & 1,985 & 1,975 & \\
\hline
\end{tabular}

Notes: Means. Significance tests indicate whether the mean for the informed groups differs from the mean for the uninformed control group. Joint F-tests in regressions of each variable on both treatment dummies are statistically insignificant. Observations weighted by survey weights to ensure national representativeness. Significance levels: ${ }^{*} \mathrm{p}<0.10,{ }^{*} \mathrm{p}<0.05,{ }^{* * *} \mathrm{p}<0.01$. Source: The 2015 public opinion survey on education in Switzerland. 
Table 2: Who supports school spending and teacher salary increases?

Descriptive evidence

\begin{tabular}{|c|c|c|c|c|}
\hline \multirow[b]{2}{*}{ Female } & \multicolumn{2}{|c|}{$\begin{array}{c}\text { School spending } \\
(1)\end{array}$} & \multicolumn{2}{|c|}{$\begin{array}{c}\text { Teacher salaries } \\
(2)\end{array}$} \\
\hline & 0.00698 & $(0.027)$ & 0.0140 & $(0.021)$ \\
\hline Parent & $0.129^{* * *}$ & $(0.033)$ & -0.0156 & $(0.025)$ \\
\hline Employed & $-0.0782^{* *}$ & $(0.032)$ & $-0.0605^{* *}$ & $(0.025)$ \\
\hline Minority & $0.0903^{* * *}$ & $(0.032)$ & $0.0938^{* * *}$ & $(0.027)$ \\
\hline Income medium & 0.0415 & $(0.035)$ & 0.0258 & $(0.027)$ \\
\hline Income high & 0.0530 & $(0.042)$ & -0.00826 & $(0.031)$ \\
\hline Income missing & -0.0106 & $(0.038)$ & 0.00876 & $(0.029)$ \\
\hline Age $35-49$ & 0.00253 & $(0.042)$ & 0.00777 & $(0.031)$ \\
\hline Age 50-64 & -0.0623 & $(0.044)$ & -0.0208 & $(0.033)$ \\
\hline Age $65+$ & $-0.148^{* * *}$ & $(0.051)$ & -0.00259 & $(0.039)$ \\
\hline High school but no B.A. & 0.00232 & $(0.037)$ & -0.00929 & $(0.028)$ \\
\hline B.A. degree or higher & 0.0231 & $(0.041)$ & 0.0499 & $(0.033)$ \\
\hline Observations & 1,495 & & 1,985 & \\
\hline$R^{2}$ & 0.027 & & 0.016 & \\
\hline
\end{tabular}

Notes: Linear probability models. Dependent variable: binary outcome of support for increased spending and salaries. Sample: control group. Regressions weighted by survey weights to ensure national representativeness. Standard errors in parentheses. Significance levels: ${ }^{*} \mathrm{p}<0.10,{ }^{* *} \mathrm{p}<0.05,{ }^{* * *} \mathrm{p}<0.01$. Source: The 2015 public opinion survey on education in Switzerland. 
Table 3: Effects of information treatment on support for school spending

\begin{tabular}{|c|c|c|c|c|c|}
\hline \multirow[t]{3}{*}{ Support for school spending to: } & \multicolumn{4}{|c|}{ increase } & \multirow[t]{2}{*}{ decrease } \\
\hline & \multirow{2}{*}{$\begin{array}{c}\text { U.S. } \\
(1)\end{array}$} & \multirow{2}{*}{$\begin{array}{c}\text { Germany } \\
(2)\end{array}$} & \multicolumn{2}{|c|}{ Switzerland } & \\
\hline & & & $(3)$ & $(4)$ & $(5)$ \\
\hline Informed & $\begin{array}{c}-0.165^{* * *} \\
(0.029)\end{array}$ & $\begin{array}{c}-0.203^{* * *} \\
(0.023)\end{array}$ & $\begin{array}{c}-0.144^{* * *} \\
(0.018)\end{array}$ & $\begin{array}{c}-0.146^{* * *} \\
(0.018)\end{array}$ & $\begin{array}{c}0.020^{* * *} \\
(0.007)\end{array}$ \\
\hline Controls & no & no & no & yes & no \\
\hline Control mean & 0.599 & 0.705 & 0.541 & & 0.031 \\
\hline Information effect/Control mean & -0.276 & -0.288 & -0.267 & & 0.633 \\
\hline Observations & 2,646 & 3,128 & 2,972 & 2,972 & 2,972 \\
\hline$R^{2}$ & 0.081 & 0.110 & 0.021 & 0.037 & 0.002 \\
\hline
\end{tabular}

Notes: Linear probability models. Dependent variable: binary outcome of support for increased (column 5: decreased) spending. Randomized experimental groups: Informed $=$ respondents informed about current school spending levels. Controls include gender, parental and employment status, income (four categories), age (four categories), and education (three categories). Regressions weighted by survey weights to ensure national representativeness. Standard errors in parentheses. Significance levels: ${ }^{*} \mathrm{p}<0.10,{ }^{* *} \mathrm{p}<0.05$, *** $\mathrm{p}<0.01$. Source: The 2015 public opinion survey on education in Switzerland and Lergetporer et al. (2018). 
Table 4: Effects of information treatment on support for teacher salary

\begin{tabular}{|c|c|c|c|c|c|}
\hline \multirow[t]{3}{*}{ Support for teacher salaries to: } & \multicolumn{4}{|c|}{ increase } & \multirow[t]{2}{*}{ decrease } \\
\hline & \multirow{2}{*}{$\begin{array}{c}\text { U.S. } \\
(1)\end{array}$} & \multirow{2}{*}{$\begin{array}{c}\text { Germany } \\
(2)\end{array}$} & \multicolumn{2}{|c|}{ Switzerland } & \\
\hline & & & $(3)$ & $(4)$ & $(5)$ \\
\hline Informed & $\begin{array}{c}-0.242^{* * *} \\
(0.023)\end{array}$ & $\begin{array}{c}-0.120^{* * *} \\
(0.014)\end{array}$ & $\begin{array}{c}-0.074^{* * *} \\
(0.013)\end{array}$ & $\begin{array}{c}-0.075^{* * *} \\
(0.013)\end{array}$ & $\begin{array}{c}0.064^{* * *} \\
(0.011)\end{array}$ \\
\hline Controls & no & no & no & yes & no \\
\hline Control mean & 0.617 & 0.290 & 0.265 & & 0.094 \\
\hline Information effect/Control mean & -0.392 & -0.415 & -0.280 & & 0.677 \\
\hline Observations & 2,639 & 4,127 & 3,960 & 3,960 & 3,960 \\
\hline$R^{2}$ & 0.059 & 0.020 & 0.008 & 0.018 & 0.009 \\
\hline
\end{tabular}

Notes: Linear probability models. Dependent variable: binary outcome of support for increased (column 5: decreased) teacher salaries. Randomized experimental group: Informed $=$ respondents informed about current teacher salary levels. Controls include gender, parental and employment status, income (four categories), age (four categories), and education (three categories). Regressions weighted by survey weights to ensure national representativeness. Standard errors in parentheses. Significance levels: $* \mathrm{p}<0.10, * *$ $\mathrm{p}<0.05,{ }^{* * *} \mathrm{p}<0.01$. Source: The 2015 public opinion survey on education in Switzerland and Lergetporer et al. (2018). 
Table 5: Heterogeneous treatment effects by demographic subgroups

\begin{tabular}{|c|c|c|c|c|}
\hline & \multicolumn{2}{|c|}{ School spending } & \multicolumn{2}{|c|}{ Teacher salary } \\
\hline & $\begin{array}{c}\text { No/Low } \\
(1)\end{array}$ & $\begin{array}{c}\text { Yes/High } \\
(2)\end{array}$ & $\begin{array}{c}\text { No/Low } \\
(3)\end{array}$ & $\begin{array}{c}\text { Yes/High } \\
(4)\end{array}$ \\
\hline Female & $\begin{array}{c}-0.102^{* * *} \\
(0.026)\end{array}$ & $\begin{array}{c}-0.187^{* * * *} \\
(0.025)\end{array}$ & $\begin{array}{c}-0.060^{* * *} \\
(0.019)\end{array}$ & $\begin{array}{c}0.088^{* * *} \\
(0.018)\end{array}$ \\
\hline Parent & $\begin{array}{c}-0.093^{* * * *} \\
(0.030)\end{array}$ & $\begin{array}{c}-0.175^{* * *} \\
(0.023)\end{array}$ & $\begin{array}{c}-0.105^{* * *} \\
(0.022)\end{array}$ & $\begin{array}{c}-0.055^{* * *} \\
(0.017)\end{array}$ \\
\hline Employed & $\begin{array}{c}-0.166^{* * * *} \\
(0.028)\end{array}$ & $\begin{array}{c}-0.128^{* * *} \\
(0.024)\end{array}$ & $\begin{array}{c}-0.099 * * * \\
(0.021)\end{array}$ & $\begin{array}{c}-0.056^{* * *} \\
(0.017)\end{array}$ \\
\hline Minority & $\begin{array}{c}-0.139^{* * *} \\
(0.020)\end{array}$ & $\begin{array}{c}-0.173^{* * *} \\
(0.040)\end{array}$ & $\begin{array}{c}-0.059^{* * *} \\
(0.015)\end{array}$ & $\begin{array}{c}-0.141^{* * *} \\
(0.032)\end{array}$ \\
\hline Income & $\begin{array}{c}-0.119^{* * * *} \\
(0.026)\end{array}$ & $\begin{array}{c}-0.168^{* * *} \\
(0.026)\end{array}$ & $\begin{array}{c}-0.083^{* * *} \\
(0.019)\end{array}$ & $\begin{array}{c}-0.065^{* * *} \\
(0.019)\end{array}$ \\
\hline Age & $\begin{array}{c}-0.152^{* * *} \\
(0.024)\end{array}$ & $\begin{array}{c}-0.135^{* * *} \\
(0.027)\end{array}$ & $\begin{array}{c}-0.086^{* * *} \\
(0.018)\end{array}$ & $\begin{array}{c}-0.057^{* * *} \\
(0.020)\end{array}$ \\
\hline Education & $\begin{array}{c}-0.162^{* * *} \\
(0.022)\end{array}$ & $\begin{array}{c}-0.101^{* * *} \\
(0.033)\end{array}$ & $\begin{array}{c}-0.082^{* * *} \\
(0.015)\end{array}$ & $\begin{array}{c}-0.060^{* *} \\
(0.026)\end{array}$ \\
\hline Conservative & $\begin{array}{c}-0.141^{* * * *} \\
(0.032)\end{array}$ & $\begin{array}{c}-0.147^{* * *} \\
(0.022)\end{array}$ & $\begin{array}{c}-0.081^{* * * *} \\
(0.026)\end{array}$ & $\begin{array}{c}-0.064^{* * *} \\
(0.015)\end{array}$ \\
\hline
\end{tabular}

Notes: Subgroup estimations by characteristic indicated in first column. Binary variables (female, parent, employed, minority): No=subgroup where the status is wrong; Yes=subgroup where the status is true. Income: Low=subgroup where either low or missing; High=subgroup where income is either medium or high. Age: Low=subgroup where age is below 49; High=subgroup where age is 50 or above. Education: Low=below B.A. degree; High = B.A. degree or higher. Conservative: No = respondent self-reported to be more left on a 10-point left-right-scale $(<5)$. Yes $=$ respondent self-reported to be more right on a 10-point left-right-scale $(\geq 5)$. Linear probability models. Dependent variable: binary outcome of support for increased spending (columns 1-2) resp. increased teacher salaries (columns 3-4). Randomized experimental groups: Informed= respondents informed about current levels of school spending (columns 1-2) resp. teacher salaries (columns 3-4). Regressions weighted by survey weights to ensure national representativeness. Standard errors in parentheses. Significance levels: ${ }^{*} \mathrm{p}<0.10,{ }^{* *} \mathrm{p}<0.05,{ }^{* * *} \mathrm{p}<0.01$. Source: The 2015 public opinion survey on education in Switzerland. 
Table 6: Heterogeneity of information effects with respect to framing of information

\begin{tabular}{lccccc}
\hline \hline & \multicolumn{2}{c}{ School spending } & & \multicolumn{2}{c}{ Teacher salary } \\
\cline { 2 - 3 } \cline { 5 - 5 } & $(1)$ & $(2)$ & & $(3)$ & $(4)$ \\
\hline Informed & $-0.144^{* * *}$ & $-0.146^{* * *}$ & & $-0.074^{* * *}$ & $-0.075^{* * *}$ \\
Informed $\times$ relative spending & $(0.018)$ & $(0.018)$ & & $(0.013)$ & $(0.013)$ \\
& -0.002 & 0.000 & & 0.015 & 0.017 \\
Informed $\times$ total spending & $(0.018)$ & $(0.018)$ & & $(0.013)$ & \\
& 0.018 & 0.019 & & yes \\
Controls & $(0.018)$ & $(0.018)$ & & no & \\
Control mean & no & yes & & 0.265 & 5,931 \\
Observations & 0.541 & & 5,931 & 0.016 \\
$R^{2}$ & 5,933 & 5,933 & 0.006 & \\
\hline \hline
\end{tabular}

Notes: Linear probability models. Dependent variable: binary outcome of support for increased spending (columns 1-2) resp. increased teacher salaries (columns 3-4). Randomized experimental groups: Informed = indicator that respondents are informed about school spending per student (columns 1-2) resp. annual teacher salaries (columns $3-4$ ). Informed $\times$ relative spending $=$ information treatment indicator interacted with an indicator for respondents informed about current annual levels of school spending per student relative to the tax revenue over 16 years of an average income earner (columns 1-2) resp. annual teacher salaries relative to the income of average income earner (columns 3-4). Informed $\times$ total spending $=$ information treatment indicator interacted with an indicator for respondents informed about current total levels of school spending per student for the duration of 9 years (columns 1-2). Controls include gender, parental and employment status, income (four categories), age (four categories), and education (three categories). Regressions weighted by survey weights to ensure national representativeness. Standard errors in parentheses. Significance levels: ${ }^{*} \mathrm{p}<0.10,{ }^{* *} \mathrm{p}<0.05$, ${ }^{* *} \mathrm{p}<0.01$. Source: The 2015 public opinion survey on education in Switzerland. 